Jurnal Evaluasi dan Pembelajaran

Volume 3 Nomor 1, Tahun 2021

Available online at https://jepjurnal.stkipalitb.ac.id/index.php/hepi

\title{
PENDEKATAN INQUIRI UNTUK MENINGKATKAN AKTIVITAS DAN PRESTASI BELAJAR MATEMATIKA SISWA
}

\author{
Rodiah Azma \\ SD Negeri 4 Sawah Lama
}

\begin{abstract}
Abstrak
Tujuan penelitian adalah untuk meningkatkan aktivitas dan prestasi belajar matematika KPK dan FPB menggunakan pendekatan Inquiri pada siswa kelas V SD Negeri 4 Sawah Lama Bandar Lampung Tahun Pelajaran 2019/ 2020. Metode penelitian adalah penelitian tindakan kelas (PTK) dilakukan salam tiga siklus yang terdiri dari perencanaan, pelaksanaan, pengamatan dan refleksi di setiap siklus. Hasil penelitian menunjukkan peningkatan aktivitas belajar Siklus I 70\%, Siklus II 80\% dan Siklus III 88\% dan prestasi belajar sisklus I rata-rata 62, siklus II 72, dan siklus III 77. Berdasarkan hasil penelitian, pendekatan inquiri dapat meningkatkan aktivitas dan prestasi belajar matematika KPK dan FPB pada siswa kelas V SD Negeri 4 Sawah Lama Bandar Lampung Tahun Pelajaran 2019/ 2020.
\end{abstract}

Kata Kunci: Aktifitas, Inquiri, Prestasi Belajar

\begin{abstract}
The research objective was to increase the activity and achievement of learning mathematics from the Corruption Eradication Commission and FPB using the inquiry approach in grade V SD Negeri 4 Sawah Lama Bandar Lampung for the academic year 2019/2020. The research method was classroom action research (CAR) which was carried out in three cycles consisting of planning, implementation, observation and reflection in each cycle. The results showed an increase in learning activities in Cycle I 70\%, Cycle II $80 \%$ and Cycle III 88\% and learning achievement in cycle I averaged 62, cycle II 72, and cycle III 77. Based on the research results, the inquiry approach can increase activity and achievement. learn mathematics from the Corruption Eradication Commission and FPB in grade V SD Negeri 4 Sawah Lama Bandar Lampung for the 2019/2020 academic year.
\end{abstract}

Keywords: Activities, Inquiries, Learning Achievement

\section{Pendahuluan}

Pembelajaran merupakan komunikasi dari dua arah, mengajar dilakukan oleh pihak guru sebagai pendidik, sedangkan belajar dilakukan oleh peserta didik sebagai murid (Sagala, 2005:61).

Keberhasilan suatu pembelajaran tergantung bagaimana interaksi antara guru dengan siswa. Interaksi guru dengan siswa dapat berjalan dengan baik apabila guru dalam mengelola kelas menggunakan strategi pembelajaran yang relevan. Dalam mengelola kelas langkah awal yang perlu diketahui oleh guru adalah, dengan siapa atau siswa yang bagaimana yang akan dihadapi. Tanpa paham tentang kondisi peserta didik mustahil guru 
dapat memilih strategi pembelajaran yang tepat dan materi pembelajaran yang sesuai. Untuk pembelajaran Matematika yang menjadi fokus dalam pembelajaran adalah adanya interaksi antara siswa dengan objek atau alam secara langsung, sehingga siswa dapat menemukan konsep dan membangun dalam struktur kognitifnya.

Dalam pembelajaran Matematika materi yang satu sering mendasai materi yang lain, sehingga guru sangat perlu memperhatikan materi prasyarat untuk mempelajari topik tertentu. Selain itu tahap berfikir siswa SMP masih dalam tahap berfikir konkrit, sehingga dalam menyampaikan materi guru perlu memperhatikan latar belakang siswa yang akan diajarkannya dan sarana atau peraga yang akan Matematika yang dipakai sebagai alat bantu mengajar agar siswa lebih cepat menyerap materi yang diberikan. Alat peraga yang dipakai guru dapat berupa benda-benda nyata yang ada di sekitarnya, atau benda konkrit yang dapat lebih meningkatkan Aktivitas dan Prestasi Belajar KPK dan FPB Pada Siswa Kelas V SD Negeri 4 Sawah Lama Bandar Lampung.

Sekalipun banyak mengalami perubahan, tetapi pendekatan dan metode yang dilakukan pendidik tidak banyak mengalami perubahan, hal ini mungkin disebabkan kebiasaan pendidik dalam membelajar materi pelajaran, sehingga tampak peserta didik tidak banyak melakukan aktifitas belajar, peserta didik hanya secara pasif mendengarkan ceramah yang diberikan pendidik.

Dari hasil pengamatan dilakukan, diperoleh aktivitas belajar siswa pada siswa kelas V SD Negeri 4 Sawah Lama saat mengikuti materi pelajaran Matematika KPK dan FPB rendah dan pada catatan prestasi belajar mata pelajaran Matematika KPK dan FPB diperoleh bahwa hasil nilai ulangan harian yang diperoleh siswa juga rendah. Hal ini mungkin disebabkan karena materi pelajaran tersebut juga masih dianggap sulit, baik bagi siswa maupun bagi guru, dimana guru itu sendiri harus bekerja keras untuk menguasai materi pelajaran dan pendekatan pembelajaran yang tepat untuk menyampaikan materi pelajaran tersebut.

Aktivitas adalah suatu kegiatan yang dilakukan individu untuk memperoleh perubahan kea rah yang positif baik dalam unsure kognitif, efektif maupun psikomotor. Menurut Mulyono (2001:26), aktivitas artinya "kegiatan / keaktifan". Jadi segala sesuatu yang dilakukan atau kegiatan-kegiatan yang terjadi baik fisik maupun non fisik merupakan suatu aktifitas. Sedangkan belajar menurut Oemar Hamalik (2001:28), adalah "suatu proses perubahan tingkah laku individu melalui interaksi dengan lingkungan". Aspek tingkah laku tersebut adalah pengetahuan, pengertian, kebiasaan, keterampilan, apresiasi, emosional, hubungan sosial, jasmani, etis ayau budi pekerti, dan sikap. Jika seseorang telah belajar maka akan terlihat terjadinya perubahan pada salah satu atau beberapa aspek tingkah laku tersebut. Selanjutnya, Sardiman AM mengatakan bahwa pada perinsipnya belajar merupakan berbuat atau melakukan untuk mengubah tingkah laku. Tidak ada belajar kalau tidak ada aktivitas (Sudirman, 2004:99).

Pada kurikulum 2006 maupun 2019 yaitu awal tahun, guru dituntut untuk menentukan kriteria ketuntasan minimum, untuk mata pelajaran Matematika KPK dan FPB ketuntasan minimal (KKM) untuk kelas V SD Negeri 4 Sawah Lama adalah 6,5 dan apabila ada siswa yang memperoleh nilai dibawah nilai ketuntasan minimum, maka guru wajib mengadakan remedial sampai peserta didik mencapai nilai ketuntasan minimum, tetapi setelah diadakan ulangan harian didapati banyak siswa kelas V SD Negeri 4 Sawah Lama yang memperoleh nilai di bawah ketuntasan minimum, hal ini mungkin disebabkan oleh pendekatan pembelajaran yang dilakukan kurang sesuai dengan kemampuan siswa.

Kebiasaan yang sering dilakukan peserta didik adalah menentukan bahan dan metode pembelajaran, sedangkan siswa menerima begitu saja sehingga aktivitas siswa terbatas hanya pada mendengarkan, mencatat, menjawab pertanyaan jika guru mengajukan pertanyaan. Para siswa hanya bekerja karena atas perintah guru menurut cara yang ditentukan guru, begitu juga cara berpikir siswa bergaris pada apa yang diberikan guru. 
Pembelajaran semacam ini membuat peserta didik menjadi pasif dan tidak mendorong peserta didik untuk berpikir dan beraktifitas karena yang banyak berkreativitas adalah guru dan guru dapat dengan bebas menentukan segala sesuatu yang dikehendakinya. Hal semacam ini jelas tidak sesuai dengan hakikat peserta didik selaku subjek belajar.

Pendekatan inquiri merupakan pendekatan mengajar yang berusaha meletakkan dasar dan mengembangkan cara berpikir ilmiah. Pendekatan ini menempatkan banyak siswa lebih banyak belajar mandiri, mengembangkan keaktifan dalam memecahkan masalah. Siswa betul-betul ditempatkan sebagai subyek belajar. (Sagala, 2003:196).

Pendekatan inquiri adalah salah satu pendekatan pembelajaran yang dapat merubah cara pembelajaran yang tradisional. Dimana dalam pendekatan ini tidak hanya menuntut guru yang banyak berkreativitas, tetapi justru menuntut siswa yang banyak melakukan aktifitas belajar dalam proses pembelajaran.

\section{Metode}

Metode penelitian adalah penelitian tindakan kelas (PTK) dilakukan salam tiga siklus yang terdiri dari perencanaan, pelaksanaan, pengamatan dan refleksi di setiap siklus. Penelitian ini dilakukan pada semester ganjil tahun pelajaran 2019/2020 selama tiga bulan yaitu pada bulan Agustus sampai bulan Oktober 2019. Subjek dalam penelitian ini adalah siswa Kelas V SD Negeri 4 Sawah Lama Bandar Lampung sebanyak 40 siswa.

\section{Hasil dan Pembahasan}

Berdasarkan penelitian tindakan kelas pada siklus I, maka dapat dikatakan bahwa (1) Prestasi belajar Matematika KPK dan FPB setelah siswa mengikuti tes didapat hasil nilai tertinggi 70, nilai terendah 55 dan nilai rata-rata 62. Dari hasil yang didapat maka dapat disimpulkan bahwa prestasi belajar Matematika KPK dan FPB belum mencapai kriteria keberhasilan. Dari hasil yang didapat maka disimpulkan bahwa prestasi belajar Matematika KPK dan FPB belum mencapai criteria keberhasilan sebesar 65 (diatas Kriteria Kelulusan Minimum). Berdasarkan hasil pada siklus I maka perlu dilakukan siklus II. (2) Aktifitas belajar siswa pada siklus I mengalami peningkatan tiap pertemuannya. Pada pertemuan pertama jumlah siswa yang aktif sebesar $57 \%$ dari siswa yang berjumlah 40 . Pada pertemuan kedua sebesar $60 \%$ dan ketiga $67 \%$.

Pada siklus II, diperoleh hasil yakni (1) Prestasi belajar Matematika KPK dan FPB setelah siswa mengikuti tes didapat hasil nilai tertinggi 90, nilai terendah 60 dan nilai ratarata 72 . Namun hanya satu siswa yang mencapai nilai 90, maka perlu dilakukan siklus ke III. (2) Aktifitas belajar siswa pada siklus II mengalami peningkatan tiap pertemuannya. Pada pertemuan pertama jumlah siswa yang aktif sebesar $78 \%$ dari siswa yang berjumlah 40 . Pada pertemuan kedua sebesar $78 \%$ dan ketiga $85 \%$.

Pada siklus III, diperoleh hasil (1) aktifitas guru dalam pembelajaran menunjukkan kategori sangat baik. (2) Hasil pengamatan aktifitas siswa yamg sesuai dengan pembelajaran (on task) menunjukkan peningkatan yang pesat. (3) Hasil pengamatan aktifitas siswa yang tidak sesuai dengan pembelajaran (off task) menunjukkan hasil sebanyak 17 siswa aktifitasnya dikategorikan baik dan 23 siswa dikategorikan aktifitas belajarnya sangat baik. (4) Prestasi belajar Matematika KPK dan FPB setelah siswa mengikuti tes didapat hasil nilai tertinggi 90, nilai terendah 65 dan nilai rata-rata $77 \mathrm{Hal}$ ini menunjukkan keberhasilan sudah tercapai. Oleh karena itu, penelitian ini tidak perlu dilanjutkan lagi.

Peran guru dalam pendekatan ini adalah pembimbing belajar dan fasilitator belajar. Tugas utama guru adalah memilih masalah yang perlu diberikan ke kelas untuk dipecahkan. Guru juga dituntut untuk menyediakan sumber belajar, mengadakan bimbingan dan 
pengawasan serta guru tidak boleh ikut campur tangan atau intervensi terhadap kegiatan siswa dalam pemecahan masalah.

Dalam penelitian tindakan kelas ini yang telah dilakukan dengan tema peningkatan aktivitas dan prestasi belajar pada mata pelajaran Matematika KPK dan FPB di kelas V SD Negeri 4 Sawah Lama Bandar Lampung pada semester ganjil tahun pelajaran 2019/2020, dimana penelitian itu terdiri dari tiga siklus, ternyata dapat meningkatkan aktivitas guru dalam pembelajaran, meningkatkan aktivitas siswa dalam pembelajaran dan meningkatkan prestasi belajar siswa.

Peningkatan aktivitas ini tidak lepas dari peran seorang guru, selain itu bagaimana upaya mahasiswa untuk aktif agar prestasi belajar juga meningkat. Ahmadi (Juwita, 2020) untuk mendapatkan hasil belajar yang tinggi siswa harus melakukan semua aspek aktivitas belajar yaitu memperhatikan guru saat menjelaskan, Aktif menjawab pertanyaan guru, Aktif bertanya kepada guru, Mengerjakan latihan dan Aktif berdiskusi dengan teman

\section{Simpulan}

Berdasarkan hasil penelitian dan pembahasan, dapat disimpulkan:

1. Aktivitas belajar meningkat tiap siklusnya, siklus I 70\%, Siklus II 80\% dan Siklus III $88 \%$.

2. Prestasi belajar meningkat tiap siklusnya, sisklus I rata-rata 62 , siklus II 72 , dan siklus III 77.

\section{Daftar Pustaka}

Al Fasani, Judi, \& Naif, Fauzan. 1984. Kunci Sukses Belajar bagi Pelajar dan Mahasiswa. Surabaya: Aneka Ilmu.

Djamarah, Syaiful Bahri. 2002. Rahasia Sukses Belajar. Rineka Cipta. Jakarta.

Juwita, Ratna. 2020. Penggunaan Model Pembelajaran Snowball Throwing Untuk Meningkatkan Aktivitas dan Hasil Belajar PKn Siswa Kelas XII IPS SMA Negeri 15 Bandar Lampung. Jurnal Evaluasi dan Pembelajaran Vol 2(2).

Sagala, Syaiful. 2003. Konsep dan Makna Pembelajaran. Alfabeta. Bandung.

Standar Kopetensi dan Kopetensi Dasar Mata Pelajaran Pendidikan Matematika KPK FPB. 2004. Departemen Pendidikan Nasional.

Sumanto, Wasty. 1987. Psikologi Pendidikan. Jakarta: PT Bina Aksara.

Undang-undang Sisdiknas (Sistem Pendidikan Nasional). 2003. (UU RI No. 20 Tahun 2003). 2006. Jakarta: Sinar Graha.

Winkel, Ws. 1984. Bimbingan dan Konseling di Sekolah Menengah Atas. Jakarta: PT.

Gramedia. 